\title{
Basrah experience among 6404 patients with COVID-19
}

1-Saad S.Hamadi Al-Taher,MD :Email:saadenoor@yahoo.com

2-Abbas K AlKanan,MD :Email: abass kanan2004@yahoo.com

3-Mohammad N. Fares,PhD: Email: mahmod.faris@uobasrah.edu.iq

4-Nihad Q. Mohammed,MD :Email:nihadqasim07@gmail.com

5-Ali Raheem Al-Jabery,MD :Email: alinz12@yahoo.com

6-Awatif A. Habeeb,PhD :Email: awatif.who@gmail.com

*7-Abbas Ali Mansour ,MD :Email: abbas.mansour@fdemc.iq

\section{1,3,5,6,7 University of Basrah, Basrah, Iraq}

2,4, Basrah Health Directorate, Basrah, Iraq

${ }^{*}$ Corresponding author : Abbas Ali Mansour

University of Basrah ,Hattin Post Office P.O Box: 142

Basrah - 61013. Phone: 009647801403706

Researcher ID: AAE-5833-2019

ORCID ID: http://orcid.org/0000-0001-8083-6024

Email: abbas.mansour@fdemc.iq

Iraq 
medRxiv preprint doi: https://doi.org/10.1101/2020.10.19.20215384; this version posted October 29, 2020. The copyright holder for this preprint (which was not certified by peer review) is the author/funder, who has granted medRxiv a license to display the preprint in perpetuity.

All rights reserved. No reuse allowed without permission.

Abstracts

Background: The first case of COVID-19 report in Basrah was in early March 2020. This study aimed to assess some of the characteristics of patients with COVID-19 in Basrah for the period from March, $4^{\text {th }}$ to September , $8^{\text {th }} 2020$.

Methods: Retrospective database analysis of the University of Basrah database. All RT-PCR positive patients during the study period were enrolled.

Results: Of 6404 patients included, male constituted $54.8 \%$. Healthcare workers constituted $11.4 \%$ of the infected people. Of health care workers $16.1 \%$ were physicians. The mean age for the whole cohort was $39 \pm 16.7$ years; adolescents and children younger than 20 years constituted $12.4 \%$. The peak age was $31-40$ years, those aged 61 years or more constituted $9.8 \%$ only. The case fatality rate was $3 \%$ (males $55.2 \%$ and females $44.8 \%$ ). No death was reported in adolescents or children. The highest death rate was among those age 61 years or more.

Conclusion: The situation of COVID-19 infection in Basrah, Iraq is evolving like other countries. Furthers studies are needed to assess associated comorbidities, treatment lines, outcomes and variables associated with mortality.

Keywords: COVID-19, case fatality rate, Basrah, Iraq

March 11, 2020 the World Health Organization established COVID-19 as pandemic after its first appearance in Wuhan, China in December 2019. This pandemic uncovered major threats to the health system of all countries. Clearly, it shows how fragile the health structure worldwide. The high number of healthcare workers infected till now despite all the recommendation of personal protections uncovers disastrous gaps in the knowledge on the disease. The care for patients with noncommunicable diseases faced tragic situation because of shift of almost all care toward patients with COVID-19.(1)

The social distancing causes an unpreceded direct and indirect psychological trauma including the direct effect on economy. (2)

Telemedicine and teaching realignments in all school are the main global changes seen.

Paucity of symptoms, wide range of incubation period (2-14 days) and false negative reverse transcriptase PCR (RT- PCR) test were major obstacles to contain the outbreak by imposing quarantine .(3)

The first case report of COVID-19 in Iraq was in the Najaf city of an Iranian student on February 24. The city of Basrah, in the south of Iraq, reported the first case on March 9 and the first death in March 10.(4)

By the end of February 2020, the health authority of Basrah (Basrah Health Directorate) in collaboration with University of Basrah started to modify the local health system in the city to 
accommodate for this new disease including preparing one major hospital (Basrah Teaching Hospital) to receive COVID-19 cases, thereafter more than 5 hospital become equipped to deal with patients infected with COVID-19.

By the mid-June, it was decided to resume the care for non-COVID-19 patients because the number of cases from February to mid -June was not very high (around 10-20 cases daily). Unfortunately, by mid-June there was sudden increase in the number of newly discovered cases up to $250-350$ daily. During that period there were periods of alternating lockdown and relaxation until $24^{\text {th }}$ of September, when the lockdown was totally lifted.

In the period from February to mid-June 2020, almost all COVID-19 cases were obliged by health authority to be hospitalized for at least 10 days and they need to be twice RT-PCR negative before discharge. Thereafter home isolation became the standard because of the dominance of mild cases.

Noteworthy, diabetes mellitus, specially that requiring insulin use is considered a strong risk factor for progression of COVID-19. Iraq is one of highest prevalence countries for diabetes (reaching up to $20 \%$ in Basrah). This could explain the increased number of severe cases in Basrah.(5)

This study aimed to assess some of the characteristics of patients with COVID-19 in Basrah for the period from March, $4^{\text {th }}$ to September, $8^{\text {th }} 2020$.

\section{Methods}

\section{Designs}

Retrospective database analysis of the University of Basrah database was done for the period March, $4^{\text {th }}$ to September, $8^{\text {th }} 2020$. The study was approved by the ethical committee of Basrah University.

\section{Precipitants}

All RT-PCR positive patients during this period were enrolled. Data collected by the University of Basrah.

The following patients were excluded: Negative chest computerized tomography (CT) signs and negative RT-PCR, those who died at home with no known RT-PCR status or those treated in the private sector based on inflammatory markers and or CT chest with no know RT-PCR status. 
Variables assessed -are: gender, job, residency, age distribution according to gender and age stratum. Case fatality rate and the mean age group death.

\section{Laboratory analysis and imaging}

In the period from March to end of April the samples were send to the ministry of health in Baghdad to perform the RT-PCR. At the end of April 2020 many local laboratories were established in in Basrah providing RT-PCR results within 48 hours using the WHO standard.

\section{Data analyses}

Data expressed as number and percentage of mean $\pm S D$ accordingly.

\section{Results}

Of 6404 study cohort involved, male (3489/6404) constituted 54.8\%; 33.6\% (2154/6404) were employed and (2194/2915) $75.3 \%$ of women were housewives. Healthcare workers involved in $11.4 \%$ (733/6404) of whole study cohort. Of 733 health care workers $118(16.1 \%)$ were doctors and $615(83.9 \%)$ were other health care workers. About $63 \%(4035 / 6404)$ from peripheral city districts (Table-1).

Table-1 Basic demographic data of 6404 patients with COVID-19 in Basrah.

\begin{tabular}{|c|c|c|c|}
\hline & & & $\mathrm{N}(\%)$ \\
\hline \multirow[t]{2}{*}{ Gender } & \multicolumn{2}{|l|}{ Males } & $3489(54.8)$ \\
\hline & \multicolumn{2}{|l|}{ Females } & $2915(45.2)$ \\
\hline \multirow[t]{7}{*}{ Job } & \multicolumn{2}{|c|}{ Employed (All) } & 2154(33.6) \\
\hline & \multicolumn{2}{|c|}{ Non employed } & $4250(66.4)$ \\
\hline & \multirow{3}{*}{$\begin{array}{l}\text { Healthcare } \\
\text { workers }\end{array}$} & ALL & 733/6404 (11.4) \\
\hline & & Physicians & 118/733(16.1) \\
\hline & & Others & $615 / 733(83.9)$ \\
\hline & \multicolumn{2}{|c|}{ Housewives } & $2194 / 2915(75.3)^{* *}$ \\
\hline & \multicolumn{2}{|c|}{ Employed Females } & $721 / 2915$ (24.7) \\
\hline Residency & \multicolumn{2}{|l|}{ City center } & $2369(37.0)$ \\
\hline
\end{tabular}




\begin{tabular}{|l|l|l|}
\hline & Peripheries & $4035(63)$ \\
\hline
\end{tabular}

The mean age for this cohort was $39 \pm 16.7$ year (mean age for males $39.9 \pm 16.2$ year and for females $38.8 \pm 17.5$ ) as seen in Table-2. Adolescents and children less than 20 years constitutes $12.4 \%$ with peak age of $31-40$ years in $23.2 \%$, those aged 61 years or more constituted $9.8 \%$ only.

Table-2 Distributions of 6404 patients with COVID-19 in Basrah according to age group.

\begin{tabular}{|l|l|l|}
\hline \multirow{2}{*}{ Mean age years } & Mean \pm SD & $\mathrm{N}(\%)$ or mean $\pm S D$ \\
\hline Mean age males & Mean \pm SD & $39 \pm 16.7$ \\
\hline Mean age females & Mean \pm SD & $39.9 \pm 16.2$ \\
\hline Age distribution & Less than 20 years & $38.8 \pm 17.5$ \\
\cline { 2 - 3 } & $21-30$ & $792(12.4)$ \\
\cline { 2 - 3 } & $31-40$ & $1336(20.8)$ \\
\cline { 2 - 3 } & $41-50$ & $1336(23.2)$ \\
\cline { 2 - 3 } & $51-60$ & $1314(20.5)$ \\
\cline { 2 - 3 } & 61 or more & $631(13.96)$ \\
\hline
\end{tabular}

Those who died were 192/6404 which mean case fatality rate of $3 \%$ and death in males and females seen in 106/192 (55.2\%) and 86(44.8\%) respectably. No death in adolescents or children and the highest death among those who died seen in those age 61 years or more in 88/192(45.8\%) as seen in Table 3. 
Table-3- Distributions of death among 6404 patients with COVID-19 in Basrah.

\begin{tabular}{|l|l|l|}
\hline \multirow{2}{*}{$\begin{array}{l}\text { Death according } \\
\text { to gender }\end{array}$} & Males & $\mathrm{N}(\%)$ \\
\cline { 2 - 3 } & Females & $106(55.2)$ \\
\hline $\begin{array}{l}\text { Death according } \\
\text { to age group } \\
\text { distribution }\end{array}$ & Mean age for all Mean \pm SD & $86(44.8)$ \\
\cline { 2 - 3 } & Mean age for males Mean \pm SD & $58.4 \pm 14.8$ \\
\cline { 2 - 3 } & Mean age for females Mean \pm SD & $57.6 \pm 14.7$ \\
\cline { 2 - 3 } & Less than 20 years & $59.4 \pm 14.8$ \\
\cline { 2 - 3 } & $21-30$ & $0(0.0)$ \\
\cline { 2 - 3 } & $31-40$ & $6(3.1)$ \\
\cline { 2 - 3 } & $41-50$ & $15(7.82)$ \\
\cline { 2 - 3 } & $51-60$ & $37(19.2)$ \\
\cline { 2 - 3 } & 61 or more & $84(45.8)$ \\
\hline Total death & $192 / 6404(3)$ & \\
\hline
\end{tabular}




\section{Discussion}

Underdoing RT-PCR is problem all over the worlds and only one-tenth of symptomatic patients with serology positive reported previous nasopharyngeal swabs done. $(3,6)$

Furthermore, $40 \%$ of COVID-19 may be asymptomatic making the true incidence and prevalence almost impossible to be predicted by any study as is the mortality rate.(7)

Published data on COVID-19 in Iraq are among the lowest all over the worlds. (8-12)

Males slightly affected more than females in more than halve in this study. The same gender prevalence was reported, unlike that of Saudi Arabia were males contributed to $80 \%$ of cases. $(13,14)$

Healthcare affected is around one-tenth of the total infected patients. Worldwide, among 2,035,395 community individuals there were 99,795 healthcare workers infected (adjusted HR 11.61, 95\% Cl 10.93-12.33).(15).

One-tenth of cases were adolescent and children and the peak age of affected patients was $31-40$ years in this study. In Saudi Arabia $90 \%$ of cases were adults and $10 \%$ only children and elderly, while in the western countries, the peak age is $20-29$ years. $(14,16)$

There were more deaths in males compared to women. Furthermore, around halve of deaths were are in those aged 61 years or older with case fatality rate of $3 \%$ in our cohort. The case fatality was very low in Saudi Arabia of around $0.2 \%$ and in outher countries ranging $2.7-7 \% \%$ according to the disease waves. $(17,18)$

Study limitation: We think that the prevalence of COVID-19 infection is underestimated due to multiple factors, such as: Majority of people with symptoms compatible with COVID19, do not undergo RT-PCR testing, majority of mild to moderate cases were treated in the private sector without RT-PCR testing. Beside that a lot of death at home were not labeled as COVID-19 because no tests have been done. Comorbidities and smoking status were not studied in this report and it will the project for future work.

Conclusion:Compared with COVID-19 infection in Basrah, Iraq to other countries, Basrah experienced similar burden of disease with comparable outcome. Further studies are needed to assess the comorbidities associations, treatment lines and outcome.

Competition of interest: None

Funding statement: None 
Authors contribution :All authors contributed equally to this work.

\section{References}

1. Volpe M, Gallo G. COVID-19 and the Forgotten Majority. High Blood Press Cardiovasc Prev. 2020;27(5):339.

2. Razai MS, Oakeshott $P$, Kankam H, Galea S, Stokes-Lampard H. Mitigating the psychological effects of social isolation during the covid-19 pandemic. BMJ. 2020;369:m1904.

3. Coleman JJ, Manavi K, Marson EJ, Botkai AH, Sapey E. COVID-19: to be or not to be; that is the diagnostic question. Postgrad Med J. 2020;96(1137):392-8.

4. OCHA Iraq. Iraq: COVID-19 Situation Report No.1, 27 February 20202020 [cited 2020 February 27]. Available from: https://reliefweb.int/report/iraq/iraq-covid-19-situationreport-no1-27-february-2020.

5. Mansour AA, Al-Maliky AA, Kasem B, Jabar A, Mosbeh KA. Prevalence of diagnosed and undiagnosed diabetes mellitus in adults aged 19 years and older in Basrah, Iraq. Diabetes, metabolic syndrome and obesity : targets and therapy. 2014;7:139-44.

6. Pollan M, Perez-Gomez B, Pastor-Barriuso R, Oteo J, Hernan MA, Perez-Olmeda M, et al. Prevalence of SARS-CoV-2 in Spain (ENE-COVID): a nationwide, population-based seroepidemiological study. Lancet. 2020;396(10250):535-44.

7. Brown TS, Walensky RP. Serosurveillance and the COVID-19 Epidemic in the US: Undetected, Uncertain, and Out of Control. Jama. 2020.

8. Allawi JA, Abbas HM, Rasheed JI, Sulaiman TA, Gatea AA, Al-Lami F, et al. The first 40-days experience and clinical outcomes in the management of coronavirus covid-19 crisis. Single center preliminary study. J Fac Med Baghdad. 2020.

9. Sarhan AR, Flaih MH, Hussein TA, Hussein KR. Novel coronavirus (COVID-19) Outbreak in Iraq: The First Wave and Future Scenario. medRxiv. 2020.

10. Gorial FI, Mashhadani S, Sayaly HM, Dakhil BD, AlMashhadani MM, Aljabory AM, et al. Effectiveness of Ivermectin as add-on Therapy in COVID-19 Management (Pilot Trial). medRxiv. 2020. 
11. Habib OS, AlKanan AK, Abed AH, Mohammed NQ. Epidemiological Features of COVID-19 Epidemic in Basrah Province-Southern Iraq-First Report. The Medical Journal of Basrah University (MJBU). 2020;38(1):7-18.

12. Habib OS, Jassim HA, Alshihaby WJ, Mohammed MA. The Dynamics of COVID-19 Epidemic in Basrah-Second Report. The Medical Journal of Basrah University (MJBU). 2020;38(1):19-28.

13. Jin J-M, Bai P, He W, Wu F, Liu X-F, Han D-M, et al. Gender Differences in Patients With COVID-19: Focus on Severity and Mortality. Frontiers in Public Health. 2020;8(152).

14. Alyami MH, Naser AY, Orabi MAA, Alwafi H, Alyami HS. Epidemiology of COVID-19 in the Kingdom of Saudi Arabia: An Ecological Study. Frontiers in Public Health. 2020;8.

15. Nguyen LH, Drew DA, Graham MS, Joshi AD, Guo C-G, Ma W, et al. Risk of COVID19 among front-line health-care workers and the general community: a prospective cohort study. The Lancet Public Health. 2020;5(9):e475-e83.

16. Venkatesan P. The changing demographics of COVID-19. The Lancet Respiratory Medicine. 2020.

17. Boretti A. COVID-19 fatality rate for Saudi Arabia, updated 3 June 2020. Journal of Global Antimicrobial Resistance. 2020;22:845-6.

18. Abou Ghayda R, Lee KH, Han YJ, Ryu S, Hong SH, Yoon S, et al. Estimation of global case fatality rate of coronavirus disease 2019 (COVID-19) using meta-analyses: Comparison between calendar date and days since the outbreak of the first confirmed case. International Journal of Infectious Diseases. 